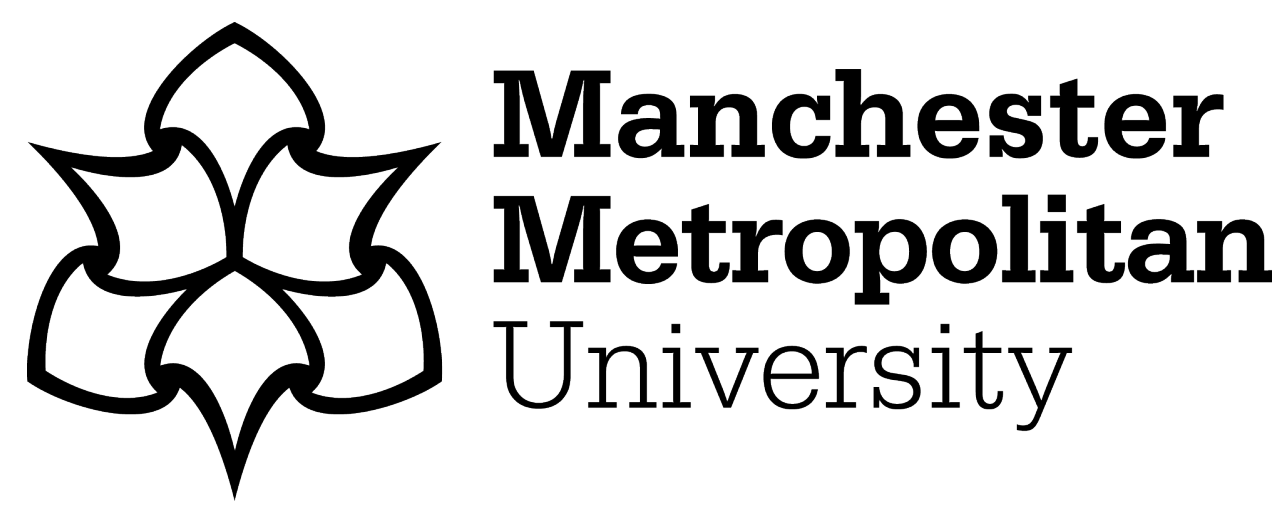

Andreoni, Valeria and Speake, Janet (2019) Urban regeneration and sustainable housing renewal trends. In: Sustainable Cities and Communities. Encyclopedia of the UN Sustainable Development Goals . Springer. ISBN 978-3-319-95717-3

Downloaded from: https://e-space.mmu.ac.uk/622100/

Version: Accepted Version

Publisher: Springer

Please cite the published version 


\title{
Urban regeneration and sustainable housing renewal trends
}

\section{Valeria Andreoni and Janet Speake}

\author{
Valeria Andreoni, PhD \\ Senior Lecturer in Economics \\ Manchester Metropolitan University Business School, All Saints Campus, Oxford Road, \\ Manchester M15 6BH, UK Email: andreoni.valeria@gmail.com \\ Janet Speake, PhD \\ Associate Professor in Geography \\ Department of Geography and Environmental Science, Liverpool Hope University, Hope \\ Park, Liverpool, L16 9JD, UK Email: speakej@hope.ac.uk
}

\section{Introduction:}

The Sustainable Development Goals (SDGs) have been specifically designed to address some of the main socio-economic and environmental issues affecting developed and developing countries. Aiming to 'improve people's lives and to protect the planet for future generation' the SDGs will be used to frame the political agenda over the next 15 years. Adopted by UN Member States in September 2015, the SDGs are composed of 17 goals and 169 targets to be achieved by 2030. Between them, goal number 11 - Sustainable Cities and Communities, is specifically oriented to make cities inclusive, safe, resilient and sustainable. Since more than half of the world population is presently living in urban context, with numbers expected to increase, the socio-economic and environmental sustainability of cities is today an important priority (UN, 2014). Urban planning, affordable houses, services provision and protection of the cultural and natural heritage are some examples of elements that would need to be considered in the design of sustainable urban realities. Within this context, an extensive academic and political debate has been devoted to how urban regeneration can be used to foster economic growth by protecting environmental quality and social cohesion. In spite of the extensive literature, however, just a limited number of studies specifically focuses in the relationships existing between SDGs and urban regeneration (Klopp and Petretta, 2017). The present chapter is oriented to fill this gap. In particular, by presenting some recent initiatives developed in the Liverpool city area (UK), the present work aims to identify examples of good practices that 
could support the design of urban regeneration policies, in line with the goals and targets of the SDGs. The chapter is structured as follow: In section 2 the concept of sustainable urban regeneration is presented. Section 3 provides an overview of the historical urban development of Liverpool and introduce the recent initiatives that have been proposed to regenerate some of the most degraded areas of the city. Section 4 analyses the Liverpool regeneration projects in line with the targets and goals of the SDGs. Section 5 concludes.

\section{Sustainable Urban regeneration - academic and political debate}

Globally, the sustainability discourse has become widespread in many contexts, including urban development and regeneration. Popularised by the 1997 Brundtland Report, which defined sustainable development as "development that meets the needs of the present without compromising the ability of future generations to meet their own needs" (United Nations General Assembly, 1987, p. 43), multiple theoretical and practical approaches have emerged within the urban setting (e.g. Vojinovic, 2014; Lang and Rothenburg, 2017). Sustainable development, within an urban framing, encompasses social sustainability and environmental sustainability, for which there are no generally accepted definitions (Vojinovic, 2014; Eisenberg and Jabareen, 2017). However, there is broad consensus that social sustainability includes a prosperous economy, healthy environment, social well-being, and sustainable communities and that environmental sustainability includes, energy conservation, minimisation of negative effects on the environment through for example recycling, urban containment and the designing-in of sustainable development principles.

Moreover, as experienced across the range of national, regional and local scales, the operationalization of social and environmental sustainable development in cities can be, in tandem, convergent or disparate and divergent. Sustainable development has become a 'portmanteau' term (Cunha and Racine, 2000); a 'go anywhere, anyplace, any situation' concept; an 'oxymoron', a contradictory term used as context for action and as a framework for focused urban (re)development. These distinctly nebulous characteristics of sustainable development are set within broad global patterns of successive 'urban crises' and their consequences (e.g. Soja, 2000; Harvey, 2007, 2012). Within this are rapid, diverse, transitions in urban form including decentralisation of population and employment and urban shrinkage/shrinking cities (e.g. Martinez-Fernandez et al., 2012; Großmann et al. 2013; Hoekstra et al., 2018), economic sectoral shifts particularly towards a culture of consumption, and the expansion of market oriented/pro-growth urban policy-making (e.g. Harvey, 2007; Brenner et al., 2010). Not only in the context of urban shrinkage, but also within situations of rapid urbanization, economic rather than environmental imperatives, 
predominate. Commodified ecological and environmental dimensions tend to be contributory motors for urban growth (e.g. Lang and Rothenburg, 2017).

For many cities in the world, the predominant driving force for urban transformation and change is the politico-economic context of neoliberalism. Since the falling levels of capital accumulation of the 1980 s associated with economic downturn, neoliberalism reflected the response of political and economic elites (Harvey, 2007; Brenner et al., 2010). A key mechanism utilized has been the switching from production to asset consumption, including land and property as a means of value extraction and profit making from the built environment (Weber, 2002; Fainstein, 2010). This has exacerbated since the turn of this century, with the emergence of intensified speculative behaviour and financialisation of the property market (Aalbers, 2016; Halbert and Attuyer, 2016) and value extraction from the built environment. These activities serve to fuel the wealth generating potential of the 'entrepreneurial city' (Hall and Hubbard 1996; Fainstein, 2010; Brenner et al., 2012). They also reinforce the entrenchment of capital in the hands of few such that $99 \%$ of the world's wealth is owned by $1 \%$ of the population (Dorling, 2014, 2015), often generated through property speculation and investment in cities. Furthermore, state power is hollowed-out (Jewson and MacGregor, 2018), rolled-back and tends towards the encouragement of business and finance (Fainstein, 2010, 2016; Halbert and Attuyer, 2016).

Driven by affluent elites, such pro-growth, financialised approaches have resulted in large scale, private sector property led regeneration schemes, within the retail, business as well as the residential sector. Their impacts are well reported e.g. Miles, 2007; Smith and Soledad Garcia Ferrari, 2012; Speake, 2017; Sklair, 2017). Although there have been moves towards encouraging community and neighbourhood regeneration (e.g. Tallon, 2010; Ghertner, 2015), these are framed largely within overarching capitalist contexts. Within this setting of neoliberal capitalism, urban regeneration and its conceptualisation and financing as business capital rather than social capital predominates (Brenner et al., 2012; Harvey, 2012). Moreover, as, for example Scharenberg and Bader (2009) have reported, there is little emphasis placed on the diversity and quality of human urban experience and the everyday lives of those who live and work in cities. Challenges to neoliberal top-down hegemonic approaches to urban development within the context of social and environmental sustainability are often made through local level, contestation and resistance 'from below' (e.g. Attuyer, 2015) and the development of alternative approaches (e.g. Thompson, 2015, 2017; Arampatzi and Nicholls,2012; Arampatzi, 2017).

It is clear that the SDGs operate within the broad politico-economic environment of the global rise of the increasing dominance of global neoliberal capitalism and cities as drivers for economic growth and sustainable (re)development. This context reflects in the five 
major ways in which SDGs differ from their immediate predecessors (e.g. the Millennium Development Goals - MDGs) and which have direct resonance with contemporary urban regeneration. Namely, SDGs are: Universally applicable; have explicit integrated economic, social and environmental dimensions; give recognition to the role of technological innovation and better data collection techniques; and make explicit linkages between global finance and global development (Parnell, 2016: Klopp and Petretta, 2017). Global in scope, the SDG framework also has local dimensions, although to date, there are comparatively few such studies - particularly in the area of regeneration. The following section presents an overview of the historical urban development of Liverpool, UK and introduces recent initiatives to regenerate some of the most socio-economically deprived and environmentally degraded areas of the city.

\section{Urban development and regeneration projects in Liverpool}

At its economic zenith in the eighteenth and nineteenth centuries, Liverpool was wealthy global mercantile city with its prosperity generated by its port, industrial and financial activities. The city experienced periods of sustained recession in the mid-twentieth century, largely a consequence of a devastating consequence of factors such as deindustrialisation, globalisation and shifts in the international division of labour. Since then the city has experienced sustained regeneration and transformation particularly in the city centre (e.g. Belchem, 2008; Sykes et al., 2013).

Throughout much of the mid to late twentieth century, Liverpool was a shrinking city in terms of economy and population (Nevin, 2010; Couch and Cocks, 2013). This was evidenced in the city's overall population decline of $27.9 \%$ between 1971 and 2001 (Speake and Fox, 2006) and in the inner-city areas (Nevin, 2010). In inner city Granby, population losses of $36 \%$ were recorded between 1971 and 1981 (Speake and Fox, 2006). The city had very high and rising levels of unemployment - it doubled from $10.6 \%$ in 1971 to $20.4 \%$ in 1981 , reaching a peak of $37.6 \%$ in inner-city Everton in 1981 (Liverpool City Council, 2005). There were high levels of acute poverty. The Breadline Britain Survey (Frayman, 1991) reported that $40 \%$ of Liverpool's population lived in poverty and $15 \%$ lived in intense poverty. The city also had hectares of obsolete commercial property, extensive areas of environmentally degraded land and large tracts of century old substandard housing (Speake and Fox, 2006). Not only this, but also the large scale 'modern', 'comprehensive renewal' state planning initiatives of the 1960s, had created large publicly owned 'council estates' on the periphery of the city, for example in Speke and Garston, which were poorly maintained and had become run-down, neglected housing areas and compounded the housing crisis. 
At this time of severe economic recession, there were major concerns about Liverpool's bleak outlook in terms of the city's sustainability and economic viability in the short and longer terms. However, since then, and despite the 2008 financial crisis and the implementation of austerity measures to combat rising public debt, the general economic standing of the city has revived (e.g. Sykes et al., 2013).

Early regeneration initiatives to generate commercial and housing development included the Merseyside Development Corporation (1981-1987) and accompanying transformation of the central and southern docks, plus various partnership initiatives such as SpekeGarston Partnership (1995-2004), and Ropewalks Partnership (1996-2001). In the case of Ropewalks, culturally-led and residential regeneration approaches were put in place for the revival of a former area of warehousing and small-scale industries adjacent to the city centre. Funding came via a portfolio of private, and public-sector sources including monies from the European Union, particularly Objective 1 and European Regional Development Funds. (Sykes et al., 2013).

In searching for alternative approaches to address the severe housing crisis, widespread housing, 'slum' clearance and the collapse of close-knit neighbourhoods, local cooperative movements emerged. Some had their roots in the 1970 s e.g. the Community Development Projects (CDPs) and the 1969-1972 Shelter Neighbourhood Action Project (SNAP), operating in a small area of inner-city Granby. SNAP and other neighbourhood action initiatives (such as the award winning Eldonian Village, a community-based housing association in Vauxhall, north Liverpool) (Sykes et al., 2013), ran counter to the City Council's policy of removal of nineteenth century housing and its replacement with 'pattern-book' Housing Market Renewal (HMR) style housing and infrastructural layout These set the seeds for later community-based initiatives, particularly in the inner-city, as direct public sector investment in housing has been rolled back as the city has turned to the dominant neoliberal drivers of private sector speculative investment in commercial and residential property.

Thus, throughout the early part of the twenty-first century, the economic regeneration and improvements to the built environment largely focused on the city centre with emphasis on private sector property development and culture led regeneration. Liverpool's status as European Capital of Culture (ECoC) in 2008 reinforced this and created incentive for the completion of existing projects and for generation of new culture-led and housing initiatives (Connolly, 2013). Predominant among the cultural developments have been the $£ 1$ billion Liverpool One retail complex, the $£ 60$ million Liverpool Echo Arena and the development of the cruise terminal at Pier Head (Speake and Pentaraki, 2017). Accompanying these major commercial projects and similar to patterns experienced elsewhere in the UK (e.g. Bromley et al., 2005; Rae, 2013), speculation in a highly 
commoditised and heated residential property market was targeted particularly at university students and young professionals. This led to large-scale expansion of buy-tolet properties in the city centre and waterfront (Couch and Dennemann, 2000; Nevin, 2010). This has resulted in an increase of population from 2,300 in 1991 to 33,540 in 2016 (Liverpool Vision, 2016) with plans for further growth. Much of this residential development has been in former warehousing districts such as Ropewalks (Couch and Dennemann, 2000; Couch et al., 2009) and the innovative creative quarter of the Baltic Triangle (Speake and Pentaraki, 2017). Organisations such as Engage Liverpool (Engage Liverpool, 2018) have worked with residents and other stakeholders towards building neighbourhood and community in areas that were not traditionally residential (Speake and Pentaraki, 2017).

Within the context of the neoliberal emphasis on housing as commodity, the marketization of public housing and the shift from state to market (Sager, 2011; Fenton et al. 2011). In England, there has been continued commodification through the roll out of the 'right to buy' process and sale of social rented dwellings to tenants, a slow decline in social renting, social housing being increasingly owned by 'not-for profit' housing associations and the demolition of obsolete housing (Fenton et al., 2011). Within Liverpool, the extensive and continuing demolition of existing housing stock in the inner-city since the 1980s has been contentious (Nevin, 2010; Thompson, 2015; 2017). However, as is characteristic of neoliberalism in which institutionalised financial investment is concentrated in the most actually and potentially lucrative areas for capital accumulation, in Liverpool, this focus has been the city centre.

Beyond the city centre and waterfront, regeneration of the adjacent inner-city areas has been limited. Extensive tracts of the city such as Everton, Anfield, and Granby/Toxteth remain among the most socio-economically disadvantaged in the UK in terms of for example, economic, education and skills and health. In 2015, these localities had indicators of deprivation that were in the highest $1 \%$ in the UK (Liverpool City Council, 2015). In these areas, there have been some attempts at local neighbourhood regeneration utilizing strategies similar to those in the city centre for example, Project Jennifer in Everton i.e. the encouragement of private sector capital investment in retail property has been encouraged by the city council in order to anchor wider neighbourhood renewal (Morris and Speake, 2012; Thompson, 2015; 2017). Their impacts have been limited and neighbourhood and housing issues remain of concern within these and other disadvantaged areas in the city such as Kensington and Islington as well as in large outer city public housing estates such as Speke and Netherley.

The approaches of community engagement and participation in regeneration activity typified by the Community Development Projects (CDPs) have evolved in Liverpool, to the 
extent that some of the most innovative examples of new forms of cooperatives and housing associations within the UK are now operating in the city. As Thompson (2017) reports, these were incorporated into Liberal Democrat controlled City Council post 1998, including moves towards more coordinated, joined-up strategic housing and neighbourhood regeneration. These included application of the LIFE model (lead in an area, influence what happens, follow by collaborating with others or exit where presence is minimal) model within the inner-city in which five 'areas of opportunity' were each assigned one lead housing association (Thompson, 2017). However subsequently, these moved back into a more top-down regeneration approach in Liverpool's 'Four Zones of Opportunity' (ZOO) within the HMR Pathfinders initiative in 2002. This delivery mechanism has become characterised by the spending of public funds to transfer land and property to the private sector, by buying out homeowners in order to demolish or 'improve' existing housing stock and eating into the provision of remaining public housing (Couch and Cocks, 2013). Such actions of the marketization of public/social housing and its implications for neighbourhood stability are highly contested by many local community action and renewal groups (e.g. Nevin, 2010; Thompson, 2015).

The approaches and outcomes of the work of some of these projects in these areas and elsewhere in the city are reported increasingly within the academic, architecture and planning literature (e.g. Nevin, 2010; Thompson, 2015; 2017; Speake and Pentaraki, 2017) and are worth sharing here.

This section concludes by presenting a short overview of five initiatives chosen to provide examples of the different approaches adopted within housing/neighbourhood revitalisation and sustainability in the city. These are: Homes for One Pound, a Liverpool City Council initiative to encourage residents and private landlords to purchase and refurbish empty homes and then present as example of community-based projects Granby Four Streets CLT, Homebaked CLT, Make Liverpool CIC and Engage Liverpool CIC. As Thompson (2017) points out, Granby Four Streets CLT and Homebaked CLT are among the very few urban CLTs in the country.

i. Homes for One Pound is a Liverpool city council led project included in a portfolio of measures designed to bring back into use 6,000 empty houses. Between 2014 and 2018, 1,500 properties returned to use (Liverpool City Council, 2018). Within this set of measures, the 'Homes for One Pound' scheme has been widely promoted and reported in the press and television, including a Channel 4 TV documentary series 'The $£ 1$ Houses: Britain's Cheapest Street'. Launched as a pilot in 2013 as a homesteading programme in the Granby Four Streets/Arnside Road area, the Homes for One Pound project there was followed by a second phase in the Webster Triangle in Picton, Wavertree. Applicants who sought to buy a house for $£ 1$ and 
then refurbish it, were required to live or work in Liverpool, be in employment, be first time buyers and agree to live in the property for five or more years. When refurbished to a standard approved by the City Council, ownership of the property would then transfer to the purchaser (Empty House Network, 2015). By 2018, in total 100 families were allocated properties with more being lined up for a later phase (Liverpool City Council, 2018). The outcomes are that families have been housed, properties renovated and there is extra income to the city council through the additional annual council (property) tax payments accrued. Conversely, it may be argued that the Homes for One Pound project has taken the property out of the public sector, reduced the availability of public social housing for rent thereby reinforcing the dominant regeneration driver of the marketization and commodification of property wherever [authors emphasis] located.

ii. Granby Four Streets Community Land Trust (CLT) has operated in inner-city Granby since 2011 and is one of the country's first CLTs. Comprising activist

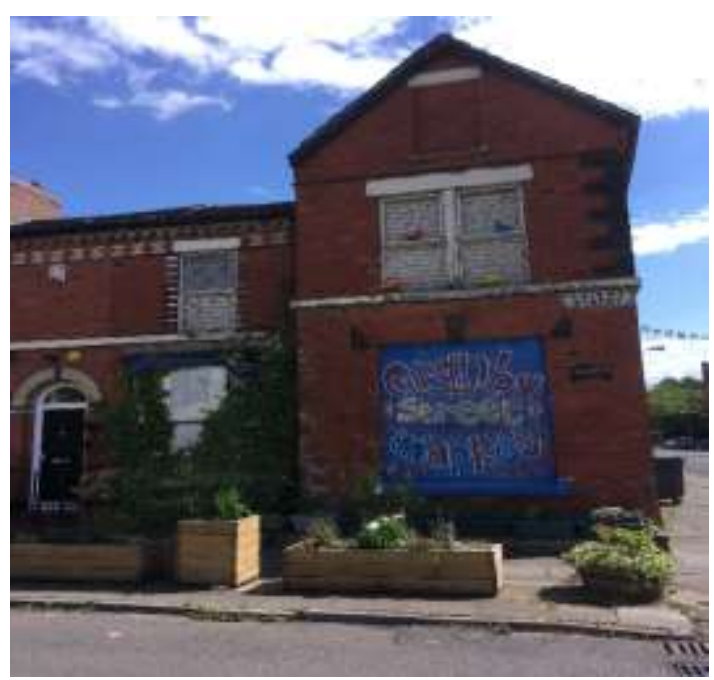
Assemble, an architects' collective. In 2015 became the first housing or regeneration project to win the prestigious Turner Prize for visual art (Thompson, 2016). Subsequently, the CLT has set up the social enterprise Granby Workshop and employs local people to make furniture and fixtures using recycled materials from within in the CLT area) (Thompson, 2017; 2018). In 2016, it was a finalist in the UN-BSHF World Habitat Awards and this created further interest both in the approaches used and in how the area is being revitalised is now becoming of interest to potential gentrifies. residents, social financiers and radical architects, it has focused on community-led rehabilitation rather than the demolition of property and has saved hundreds of houses from demolition (Thompson, 2015). It started as a guerrilla gardening project to transform vacant and derelict spaces into a public garden. It has acquired ten properties from the council with plans to self-renovate with the help of

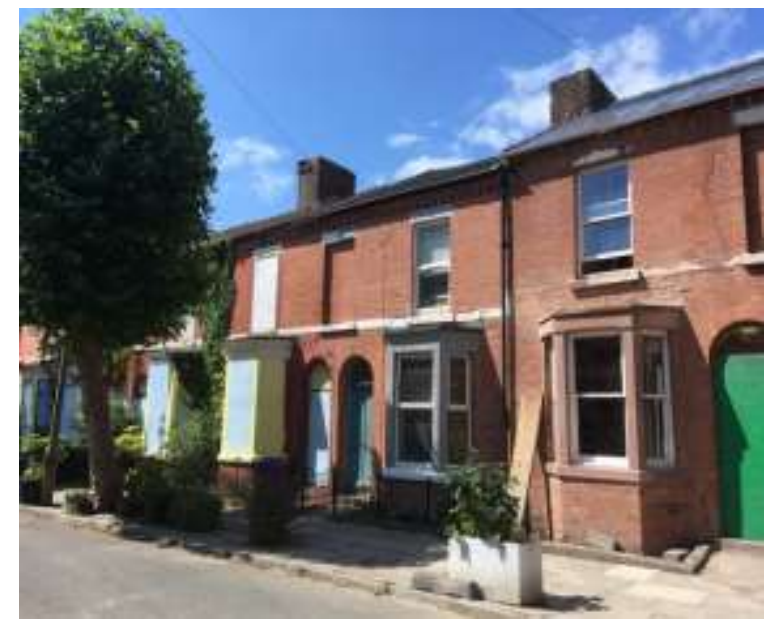


iii. Homebaked Community Land Trust (CLT) is located in inner-city Anfield in north Liverpool and developed out of an arts' based project in 2010, led by Dutch artist Jeanne van Heeswijk, called '2up2down' (the colloquial name given to the local style of terraced housing comprising two rooms downstairs and two rooms upstairs). The project encouraged local residents to re-imagine and thereby coproduce their own future by encouraging them to suggest ways to improve housing adjacent to Liverpool FC's Anfield football ground. This was followed by the creation of a cooperative bakery and café, within a setting of community-owned housing. It has as its motto "brick by brick, loaf by loaf, we build ourselves". It serves as a pivotal meeting place and provides support services for the neighbourhood. It is a partner within the wider plans for 'Anfield Village', including a project called Homefarm providing incubation space for local businesses (Thompson, 2018).

iv. Make Liverpool Community Investment Company (CIC) was established in 2012 and is located in Regent Street within the 50ha 'Ten Streets Area' of the Northern Docks. It has created 'makerspace' for the development of creative and digital industries and a space in which to "play, make and fix" (Make Liverpool, 2018). It also acts as an economic anchor within the Ten Streets Strategic Regeneration Framework (SRF), in an economically disadvantaged area of former warehouses within the Northern Docks (Thompson, 2018). As a hub for the creative industries, the 'Ten Streets' project seeks to emulate the successful work of the Baltic Creative CIC in the Baltic Triangle to east of the city centre. Residential development in the neighbourhood is intended to be small scale and/or designer led with projected potential further housing planned for the periphery (Ten Streets, 2018).

v. Engage Liverpool Community Investment Company (CIC) is a large grassroots residents' network for people living in the city centre and waterfront areas of the city became a CIC in 2013. It seeks to improve the quality of life for the estimated 35,000 residents who live there through aspirational engagement and action to bring about positive transformation and progress. It encourages residents to engage with each other and stakeholders to activate social visioning and generate the quality of urban living (Speake and Pentaraki, 2017). Engage Liverpool has created several innovative projects success as 'Grow the Baltic' (connecting residents with businesses in the Baltic Triangle area of the inner-city, 'Liverpool Air Project' and 'Blue Green Liverpool' (improving the greenspaces of streets and blue spaces of the docks and waterways) (Engage Liverpool, 2018).

In the next section, each of these projects will be discussed within the context of the SDGs. 


\section{Regeneration projects and SDGs}

As reported in Section 2, the academic and political debate on urban regeneration has focused on the idea of merging the sustainability concepts to secure a long-term economic, environmental and social well-being ( $\mathrm{Ng}$, et al., 2001; Bromley et al., 2005). Within the context of the SDGs the intention to integrate the different sustainability dimensions is made clear across the different targets included in the 'Sustainable Cities and Communities' goal. In particular, the provision of safe and affordable housing together with the intention to protect and safeguard the cultural and natural heritage are defined as fundamental factors for the promotion of an inclusive, resilient and efficient development of urban environment.

The recent renewal of the Liverpool area and the five cases reported above are successful examples of how urban policies can be designed to integrated the physical, the social and the economic aspects of development. The main characteristics of the Liverpool projects and the existing links with the targets of the SDGs are reported in Table 1, where the main socio-economic and environmental impacts are considered for each initiative reported above.

Table 1. Urban regeneration projects and SDG targets

\begin{tabular}{|c|c|c|}
\hline Project & Impacts & Targets \\
\hline $\begin{array}{l}\text { Homes for } \\
\text { One Pound }\end{array}$ & $\begin{array}{l}\text { Social: } \\
\text { - To provide affordable home } \\
\text { - } \text { regentribute to the social } \\
\text { - To create sense of community and } \\
\text { communities of neighbours } \\
\text { - To protect the cultural heritage } \\
\text { Environmental } \\
\text { - To reuse existing resources and } \\
\text { regenerate the existing capital } \\
\text { - To regenerate and improve the city } \\
\text { landscape } \\
\text { - To contribute to shift expectations } \\
\text { around derelict urban buildings - } \\
\text { refurbished and reused rather than } \\
\text { demolished } \\
\text { Economic } \\
\text { - To create market demand } \\
\text { To create opportunities for new } \\
\text { local business } \\
\text { To generate additional council tax } \\
\text { revenue }\end{array}$ & $\begin{array}{l}11.1 \text { To ensure access for } \\
\text { all to adequate, safe and } \\
\text { affordable housing and } \\
\text { basic services and upgrade } \\
\text { slums } \\
11.4 \text { To strengthen } \\
\text { efforts to protect and } \\
\text { safeguard the world's } \\
\text { cultural and natural } \\
\text { heritage } \\
11.3 \text { To enhance } \\
\text { inclusive and sustainable } \\
\text { urbanization and } \\
\text { capacity for } \\
\text { participatory, integrated } \\
\text { and sustainable human } \\
\text { settlement planning and } \\
\text { management in all } \\
\text { countries }\end{array}$ \\
\hline
\end{tabular}




\begin{tabular}{|c|c|c|}
\hline $\begin{array}{l}\text { Granby } \\
\text { Four } \\
\text { Streets } \\
\text { Community } \\
\text { Land Trust }\end{array}$ & $\begin{array}{l}\text { Social: } \\
\text { - To create links and interactions } \\
\text { among people from different } \\
\text { cultural, social and economic } \\
\text { background } \\
\text { - To contribute to the social } \\
\text { regeneration of degraded areas } \\
\text { To create sense of community and } \\
\text { communities of neighbours } \\
\text { - To protect the cultural heritage } \\
\text { Environmental } \\
\text { - To reuse existing resources and } \\
\text { regenerate the existing capital } \\
\text { - To regenerate and improve the city } \\
\text { landscape } \\
\text { To convert derelict spaces into } \\
\text { public gardens } \\
\text { To contribute to shift expectations } \\
\text { around derelict urban buildings- } \\
\text { refurbished and reused rather than } \\
\text { demolished } \\
\text { Economic } \\
\text { - To create market demand } \\
\text { - To create opportunities for new } \\
\text { local business } \\
\text { To generate additional council tax } \\
\text { revenue } \\
\text { To build skills for local communities } \\
\text { (e.g. gardening, making furniture) } \\
\text { To create international visibility: } \\
\text { BSHF World Habitat Awards }\end{array}$ & $\begin{array}{l}11.1 \text { To ensure access } \\
\text { for all to adequate, safe } \\
\text { and affordable housing } \\
\text { and basic services and } \\
\text { upgrade slums } \\
11.3 \text { To enhance } \\
\text { inclusive and sustainable } \\
\text { urbanization and } \\
\text { capacity for } \\
\text { participatory, integrated } \\
\text { and sustainable human } \\
\text { settlement planning and } \\
\text { management in all } \\
\text { countries } \\
11.4 \text { To strengthen } \\
\text { efforts to protect and } \\
\text { safeguard the world's } \\
\text { cultural and natural } \\
\text { heritage } \\
11.7 \text { To provide universal } \\
\text { access to safe, inclusive } \\
\text { and accessible, green } \\
\text { and public spaces } \\
11 . c \text { To promote the use of } \\
\text { local materials }\end{array}$ \\
\hline \multirow[t]{3}{*}{$\begin{array}{l}\text { Homebaked } \\
\text { Community } \\
\text { Land Trust }\end{array}$} & $\begin{array}{l}\text { Social: } \\
\text { - To contribute to the social } \\
\text { regeneration of degraded areas } \\
\text { - To create sense of community and } \\
\text { communities of neighbours } \\
\text { - To protect the cultural heritage } \\
\text { - To build positive expectations } \\
\text { around urban environment and } \\
\text { regeneration }\end{array}$ & $\begin{array}{l}11.3 \text { To enhance } \\
\text { inclusive and sustainable } \\
\text { urbanization and } \\
\text { capacity for } \\
\text { participatory, integrated } \\
\text { and sustainable human } \\
\text { settlement planning and } \\
\text { management in all } \\
\text { countries }\end{array}$ \\
\hline & $\begin{array}{l}\text { Environmental } \\
\text { - To regenerate and improve the city } \\
\text { landscape } \\
\text { - To contribute to shift expectations } \\
\text { around derelict urban buildings- } \\
\text { refurbished and reused rather than } \\
\text { demolished } \\
\text { Economic }\end{array}$ & $\begin{array}{l}11.4 \text { To strengthen efforts } \\
\text { to protect and safeguard } \\
\text { the world's cultural and } \\
\text { natural heritage } \\
11.7 \text { To provide universal } \\
\text { access to safe, inclusive } \\
\text { and accessible, green } \\
\text { and public spaces }\end{array}$ \\
\hline & $\begin{array}{l}\text { - To create cooperative economic } \\
\text { activities }\end{array}$ & $\begin{array}{l}\text { 11.c To promote the use of } \\
\text { local materials }\end{array}$ \\
\hline
\end{tabular}


- To provide incubation space for local businesses

\section{Make Liverpool Community Investment Company}

Social:

- To contribute to the social regeneration of degraded areas

- To create sense of community and communities of neighbours

- To protect the cultural heritage

- To create new neighbourhood in areas previously designated to industrial activities

- To build positive expectations around urban environment and regeneration

\section{Environmental}

- To regenerate and improve the city landscape

- To contribute to shift expectations around derelict urban buildingsrefurbished and reused rather than demolished

Economic

- To provide incubation space for local businesses

- To create opportunities for creative and digital industries

- To promote the creation of new business initiatives

Engage Liverpool
Social:

- To create sense of community in new neighbourhood areas

- To activate social interactions to improve quality of urban living

\section{Environmental}

- To regenerate and improve the city landscape

- To improve the environmental quality of waterfront areas

\section{Economic}

- To increase connections between residents and local business

- To create opportunities for business activities based on social interactions and urban living
11.3 To enhance

inclusive and sustainable urbanization and

capacity for participatory, integrated and sustainable human settlement planning and management in all countries

11.4 To strengthen efforts to protect and safeguard the world's cultural and natural heritage
11.3 To enhance inclusive and sustainable urbanization and capacity for participatory, integrated and sustainable human settlement planning and management in all countries

11.4 To strengthen efforts to protect and safeguard the world's cultural and natural heritage

11.6 To reduce the adverse per capita environmental impacts of cities, including by paying special attention to air quality and municipal and other waste management

11.7 To provide universal access to safe, inclusive and accessible, green and public spaces 
The regeneration projects developed in Liverpool and the related socio-economic and environmental impacts are strongly connected with most of the targets established in SDG 11. As reported in Table 1, the Liverpool initiatives provide examples of practices contributing to improve the urban environment while increasing the sense of community and the economic opportunities in disadvantaged areas. In spite of these benefits, however, an increasing integration between the projects reported above and the overall policies of urban development would be needed to strength the connections of different Liverpool areas, still characterized by large socio-economic discrepancies. The development of policies oriented to increase inclusion, opportunities and resilience (as reported in targets $11 . a$ and $11 . b$ ) and the implementation of a more integrated transport system (target 11.2) would be useful to reduce the existing differences and to increase the level of wellbeing of the overall urban environment.

\section{Conclusion}

The Liverpool study and the different projects reported here, present a useful example of how local initiatives can be utilized to reach some of the targets established in the SDGs. Despite the small case application and the differences existing between the specificities and particularities of the socio-economic and environmental settings of the Liverpool locations, the five projects presented here are a useful exemplification of the design of sustainability policies that can be adopted globally in both developed and developing countries. The implementation of the SDGs would certainly need to be adapted for the specific characteristics of the different urban environments. However, the development of projects based on community involvement, regeneration of existing dwellings and the creation of social spaces has proved to be an effective strategy for sustainable renewal of the urban environment.

\section{References:}

Aalbers MB (2016) The financialization of housing: A political economy approach. Routledge.

Arampatzi A (2017) The spatiality of counter-austerity politics in Athens, Greece: Emergent 'urban solidarity spaces'. Urban Studies, 54(9): 2155-2171.

Arampatzi A, Nicholls W J (2012). The urban roots of anti-neoliberal social movements: the case of Athens, Greece. Environment and Planning A, 44(11), 2591-2610. 
Attuyer K (2015) When Conflicts Strikes: Contesting Neoliberal Urbanism outside Participatory Structures in Inner-city Dublin. International Journal of Urban and Regional Research 39(4): 1-10.

Belchem J (2008) Liverpool 800. University of Liverpool Press.

Brenner N, Peck J, Theodore N (2010). Variegated neoliberalization: geographies, modalities, pathways. Global networks 10(2): 182-222.

Brenner N, Marcuse P, Mayer M (Eds.) (2012) Cities for people, not for profit: Critical urban theory and the right to the city. Routledge.

Bromley RDF, Tallon AR, Thomas CJ (2005) City Centre Regeneration through Residential Development: Contributing to Sustainability. Urban Studies 42: 2407-2429.

Connolly MG (2013) The 'Liverpool model(s)': cultural planning, Liverpool and Capital of Culture 2008. International Journal of Cultural Policy 19(2): 162-181.

Couch C, Fowles S, Karecha J (2009) Reurbanization and housing markets in the central and inner areas of Liverpool. Planning Practice \& Research 24(3): 321-341.

Couch C, Cock M (2013). Housing Vacancy and the Shrinking City: Trends and Policies in the UK and the City of Liverpool. Housing Studies 28(3): 499-519.

Couch C, Dennemann A (2000). Urban regeneration and sustainable development in Britain: The example of the Liverpool Ropewalks Partnership. Cities 17(2): 137147.

Cunha A, Racine J-B (2000) Sustainable development, the quality of urban environment and governance: Issues in urban research, or how to change the process of change. In: I Ianos, D Pumain, J-B Racine, Integrated systems and sustainability of urban life. International Geographical Union, Commission on Urban Development and Urban Life. Editura Tehnica, Bucharest: 77-100.

Eizenberg E, Jabareen Y (2017) Social Sustainability: A New Conceptual Framework. Sustainability 9: 1-16.

Empty House Network (2015) Liverpool "Homes for a Pound" scheme. 27 $7^{\text {th }}$ March, 2015. Liverpool "Homes for a Pound" scheme - major expansion on cards http://www.ehnetwork.org.uk/newsitem/liverpool-homes-pound-scheme-majorexpansion-cards

Engage Liverpool (2018) Engage Liverpool. Available at: https://www.engageliverpool.com/

Fainstein SS (2010). The just city. Cornell University Press. 
Fenton A, Tang C, Whitehead, C (2011). Market-pegged Social Rents and Local Income Distributions. Cambridge: Centre for Housing and Planning Research, University of Cambridge.

Frayman H (1991) Breadline Britain - 1990s: The findings of the television series. London: Domino Films and London Weekend Television.

Ghertner DA (2015). Rule by aesthetics: World-class city making in Delhi. Oxford, Oxford University Press.

Großmann K, Bontje M, Haase A, Mykhnenko V (2013). Shrinking cities: Notes for the further research agenda. Cities 35: 221-225.

Klopp JM, Petretta DL (2017) The urban sustainable development goal: Indicators, complexity and the politics of measuring cities. Cities 63: 92-97

Halbert L, Attuyer K (2016) Introduction: The financialisation of urban production: Conditions, mediations and transformations. Urban Studies 53(7): 1347-1361.

Hall T, Hubbard P (1996) The entrepreneurial city: new urban politics, new urban geographies? Progress in human geography 20(2): 153-174.

Harvey D (2007) A brief history of neoliberalism. Oxford University Press, USA.

Harvey D (2012). Rebel cities. Verso, London, p. 187

Hoekstra MS, Hochstenbach C, Bontje MA, Musterd S (2018). Shrinkage and housing inequality: Policy responses to population decline and class change. Journal of Urban Affairs: 1-18.

Jewson N, MacGregor S (2018) Transforming cities: contested governance and new spatial divisions. Routledge.

Lang S, Rothenberg J (2017) Neoliberal urbanism, public space, and the greening of the growth machine: New York City's High Line park. Environment and Planning A 49(8): 1743-1761.

Liverpool City Council (2005) Census 2001: Key statistics: Liverpool wards 1971/1981/1991. Liverpool: Liverpool City Council.

Liverpool City Council (2015) Index of multiple deprivation 2015: A Liverpool analysis. Liverpool City Council.

Liverpool City Council (2018) Homes for One Pound. Available at: https://liverpool.gov.uk/housing/homes-for-a-pound/

Make Liverpool (2018) Make Liverpool. Available at https://www.makeliverpool.com/ 
Martinez-Fernandez C, Audirac I, Fol S, Cunningham-Sabot E (2012). Shrinking cities: Urban challenges of globalization. International Journal of Urban and Regional Research 36(2): 213-225.

Miles M (2007). Cities and cultures. Routledge.

Morris R, Speake J (2012) Liverpool: Rebranding beyond the city centre. Geography Review: 9-13.

Nevin B (2010). Housing market renewal in Liverpool: locating the gentrification debate in history, context and evidence. Housing studies 25(5): 715-733.

Ng MK, Cook A, Chui EWT (2001) The Road Not Travelled: A Sustainable Urban Regeneration Strategy for Hong Kong. Plan. Pract. Res. 16: 171-183.

Parnell S (2016) Defining a global urban development agenda. World Development 78: 529-540.

Rae A (2013) English urban policy and the return to the city: A decade of growth, 20012011. Cities 32: 94-101.

Sager T (2011) Neo-liberal urban planning policies: A literature survey 19902010. Progress in planning 76(4): 147-199.

Scharenberg A, Bader I (2009) Berlin's waterfront site struggle. City 13: 325-335

Sklair L (2017) The Icon Project: Architecture, cities, and capitalist globalization. Oxford University Press.

Smith H, Ferrari MSG (Eds.) (2012) Waterfront regeneration: experiences in city-building. Routledge.

Soja EW (2000) Postmetropolis Critical studies of cities and regions. Wiley-Blackwell

Speake J (2017) Urban development and visual culture: Commodifying the gaze in the regeneration of Tigné Point, Malta. Urban Studies 54(13): 2919-2934.

Speake J, Fox V (2006) Liverpool: Discovering Cities. Sheffield, Geographical Association.

Speake J, Pentaraki M (2017) Living (in) the city centre, neoliberal urbanism, Engage Liverpool and citizen engagement with urban change in Liverpool, UK. Human Geographies-Journal of Studies and Research in Human Geography 11(1): 41-63.

Sykes O, Brown J, Cocks M, Shaw D, Couch C (2013). A city profile of Liverpool. Cities 35 : 299-318.

Tallon A (2010) Urban regeneration and renewal. Routledge. 
Ten Streets (2018) Ten Streets: Spatial Regeneration Project. Shedkm, How, Liverpool City Council, Ten Streets http://regeneratingliverpool.com/wpcontent/uploads/2018/02/Ten-Streets.pdf

Thompson M (2015). Between boundaries: from commoning and guerrilla gardening to community land trust development in Liverpool. Antipode 47(4): 1021-1042.

Thompson M (2016) Why the Turner Prize Isn't Enough to Resolve a Housing Crisis. Town and Country Planning 85: 221-228.

Thompson M (2017) LIFE in a ZOO: Henri Lefebvre and the (social) production of (abstract) space in Liverpool. City 21(2): 104-126.

Thompson M (2018) Playing with the rules of the game: transformative social innovation in urban regeneration. IJURR

United Nations General Assembly (1997) Report of the world commission on environment and development: Our common future. Oslo, Norway: United Nations General Assembly, Development and International Co-operation: Environment.

UN (2014) World urbanization prospects: The 2014 revision. Department of Economic and Social Affairs. Population Division (2014). Available at: http://www.un.org/en/development/desa/publications/2014-revision-worldurbanization-prospects.html

Weber R (2002) Extracting value from the city: neoliberalism and urban redevelopment. Antipode 34(3): 519-540. 